\title{
Toward a Cognitive Stylistic Contingency Theory of Translation (English-Arabic-English)
}

\author{
Hasan Said Ghazala \\ English Department, College of Social Sciences, University of Umm Al-Qura, Makkah Al-Mukarramah, Saudi Arabia \\ Email: hsghazala@uqu.edu.sa
}

\begin{abstract}
Contingency theory is a theory of communication. It is a theory of change of cultural, ideological, political, social, mental and cognitive values. These values are not constantly stative0. Many of them are temporal and susceptible to change every now and then, be they cultural, ideological, political or other values. Some terms and words of cultural or other connotations can acquire new dimensions and change bias and attitude from time to time and from nation to nation. 'Revolution' (نورة), for example, used to have pejorative connotations of bloodshed, military coups, communism, backward politics and dictatorship. However, in the light of the latest Arab Youth revolutions in Tunisia, Egypt, Syria, Libya and Yemen in 2011, the term has earned new positive dimensions of meaning, demonstrating peacefully to change the political dictatorial regimes of many Arab Countries into democratic, freely elected governments. This paper investigates the style of contingency and volume of the vicissitudes of the ideologies of different types, cultural, ideological, etc. over time. The aim is to demonstrate the new changes in the reception and perception of these ideologies and how people re-interpret and re-construct new meanings accordingly. All this is discussed in relation to the cognitive theory of translation in practice, juxtaposing the changes that may have taken place with respect to the topic concerned.
\end{abstract}

Index Terms - contingency, contingency theory, change, cognitive, cognitive stylistics, cognitive stylistic translation, ideology, revolutionary contingency, sociocultural contingency, construction / reconstruction of meaning, values

\section{INTRODUCTION}

David Birch (1995) views language as ideologically loaded. Ideologies are hidden in texts that cannot be exposed but by regarding these texts as discourse. In discourse, there are participants who act, react and interact in a context of social environment, where writers and readers produce and interpret texts against a background of ideologically naturalised beliefs and commonsense assumptions.

To Birch, communication is a dynamic activity because the whole process of 'making' meaning is a dynamic one. Meanings do not exist out of communication, nor do they exist as finalized, unchanged versions or products available to language users for use at any time. Communication is contingent upon the ways in which certain communities, institutions and individuals assign values to certain meanings in a context of power relations: the powerful over the disempowered, and the processes of naturalization and inculcation of fossilized meanings (ibid.).

Birch successfully suggests a 'contingent theory of communication' which is to him, at the same time, a theory of ideology. We make sense of the world by classifying it discursively, a view that replaces the assumption that the world has a 'natural' order and structure. To prove this, he gives a striking example of a strategy as how to explore the concept of 'colonization'. One's concerns spring from a desire to right some wrongs; to bring justice to bear in unjust situations; to find out about and interrogate the ways in which strategies of colonization persist in societies long after the colonizers seem to have left the country. Birch concludes that the politics of everyday life is never the same. He adds that "the naturalness of truth is always contingent upon who has the most control of these and other strategies. Truth is a cultural practice" (ibid.). (For more developments, models, examples and applications of contingency theory in cognitive stylistics and translation, see Birch (1989); Ghazala (2011); Simpson (2004); Stockwell, (2002a \& 2002b); Venuti, (1992,1995, 1996, 1998, 2000 \& 2004); Verdonk, (1999 \& 2002); Verdonk et al (1995); Weber(1992, 1996 \& 2005); Gavins (2000, 2005 \& 2007); Gavins \& Steen. (2003); Gutt (2000 \& 2005); Black. (2006); Jeffries (2010); and others).

Birch's theory of contingency which involves a constant change of values and attitudes is claimed in this paper to have influenced the cognitive theory of translation considerably in several ways. It sheds light on parts of meaning which cannot otherwise be traced but through careful consideration of style and its implications. Another feature of influence is the establishment of the principle of unearthing the truth which in cognitive stylistic theory lies behind the surface meaning. A third aspect of impact is the fact stated clearly by the contingency theory, namely, in principle, meaning is ideologized, culturalized, politicized and socialized by communities and is, therefore, not readily available to readers; they have to work hard to construct it in terms of their own background ideologies, cultures and attitudes. Further, dogmatized meanings and implications are not valid any more in the cognitive theories of language, style and meaning, including translation theory and practice. This leads to the conclusion that the translators' perception of 
meaning as an unchanged linguistic phenomenon can no longer be justified. (For further details see Ghazala, 2011 and 2012 (forthcoming); Newmark, 1981, 1988, 1991, 1993 and 1998; Hatim and Mason, 1997; Bassnett, 1991; SnellHornby, 1995; and others)

The following points of discussion and translated examples may offer more details, illustrations, justifications and arguments in this direction of ceaseless contingency and change of values, ideologies and meanings.

\section{POLITICO-IDEOLOGICAL TRUTH CONTINGENCY}

The very idea of truth contingency upon the dominant power, or ideology, is brilliantly illustrated in the following example from American press (quoted in Ghazala, 2011):

A Message to Israel: Time to Stop Playing the Victim Role

[...] You don't get to act like a victim any more. 'Poor little Israel' just sounds silly when you're the dominant power in the Middle East. When you've invaded several of your neighbors, bombed and ... occupied their land, and taken their homes away from them, it's time to stop acting oppressed. ... The fact is, you have the upper hand and they don't. You have sophisticated arms and they don't. You have nuclear bombs and they don't. So stop pretending to be pathetic[c...].

[...] Calling Hamas the 'aggressor' is undignified. The Gaza Strip is little more than a large Israeli concentration camp, in which Palestinians are attacked at will, starved of food, fuel, energy - even deprived of hospital supplies. They cannot come and go freely, and have to build tunnels to smuggle in the necessities of life. It would be difficult to have any respect for them if they didn't fire a few rockets back.

[...] Bombs don't ask for ID cards. Bombs are civilian killers. That's what they do. They're designed to break the spirit of a nation by slaughtering families... .

And please, Israel, try to restrain yourself from using that ridiculous argument, borrowed again from Bush[...], that Hamas leaders "hide among civilians", by living in their homes. Apparently, in the thinking of Israelis, they should all run out into an uninhabited area somewhere (try to find one in Gaza), surround themselves with flares and write in the sand with a stick, "Here I am!"

Yesterday you shelled three UN-run schools, killing several dozen children and adults... . You seem to feel you can kill whomever you like, whenever you like, and wherever you like[...]. Talk about a rogue state. The Palestinians are human. They're not dogs you can beat into submission[...]. The more you oppress people, the more people resist. (Philip Slater: From The Huffingtonpost Online Newspaper, USA: 1. 7. 2009)

Apparently, the article is loaded with defiance of the naturalness and long-established pro-Israeli (fabricated?) truth which represents Israel as a democratic, poor, wretched, defenceless and oppressed state. The American journalist, Slater has watched, sensed and suffered humanly the Israeli inhuman atrocious practices which have scandalously blown up that fake truth. Therefore, he has challenged the naturalness of such a long-lasting, anti-truth Western ideologies through the following words and expressions juxtaposed with the dogmatised ones:

Dogmatized, anti-truth ideologies

-Israel plays the Victim Role

-Long persecuted Jews

-Israel acts like a victim

-Poor little Israel

-Israel is threatened by Arabs

-Israel acts the oppressed

-The Arabs have the upper hand

-Arabs have sophisticated arms

-Both sides have no nuclear weapons

-Israel pretends to be pathetic

-Americans don't talk about Israel

-Israel's calling Hamas aggressor is dignified

-Hamas is the aggressor

-Nazi concentration camps for

oppressing Jews in Germany

-Palestinians are not respected for rocketing Israel

-Israel is anti-Nazi practices

-violation of international law is a Nazi practice Gaza is an -Israelis are not hypocrites

\section{$\underline{\text { Truthful ideologies }}$}

Stop playing the Victim Role

Jewish ... aggressor ... change

Israel should ... victim ... more.

This phrase sounds silly for it is the dominant power in the Middle East

Israel invaded them and occupied their land and taken their homes

It's time to stop acting oppressed

Israel has the upper hand and they don't.

Israel has sophisticated arms and they don't.

Israel only has nuclear weapons and Arabs don't.

Israel should stop to be pathetic.

Americans should talk about Israel as a terrorist, (being a terrorist, evil empire) rogue state and evil empire.

Israel's calling Hamas aggressor

is undignified

Israel is the aggressor.

A large Israeli concentration

camp is Gaza for starving, attacking and oppressing Palestinians.

Palestinians are respected for

rocketing Israel.

Israel is borrowing from the Nazi playbook, punishing a whole nation for the attack of a few.

violation of international law in

Israeli practice.

spare us hypocrisy 
-Israel doesn't bomb civilians

-Bombs are not for killing civilians

-Israel's argument that Hamas leaders

hide among civilians is serious

-Israel doesn't shell UN-run

institutions

-Israel takes every care to

avoid civilian casualties

-Israel doesn't kill but in self-

defence

-Israel demonstrates respect for

The UN

-Israel's macho bullying policy

has been working for decades

-The more you oppress people

the less they resist you're bombing civilians in Gaza

Israeli bombs are civilian killers in Gaza

Israel's argument that Hamas

leaders hide among civilians is ridiculous.

Yesterday you shelled three UN-

run schools in Gaza, killing several dozen children and adults

So much for "taking every care

to avoid civilian casualties".

you feel you can kill whomever,

whenever and wherever you like

you're demonstrating contempt

for the UN

your outdated policy of mach

bullying isn't working. The Palestinians are human. You cannot beat them into submission

the more you oppress people the people resist

It is astonishing how many ideologies about Israel in the West have been daringly questioned and reconsidered in this article. Whole socio-political, socio-cultural, pro-Israel and anti-Arab conceptions have been challenged and have, therefore, to be changed. Until the Israeli massacres in Gaza against children, women, civilians, stones, trees and everything, the Israelis had been enjoying the fabricated image of a poor, oppressed and civilised state. At the same time, the Arabs have been the oppressors, aggressors, uncivilised people and killers of the Jews. These have been looked at as unchallenged natural truths by Western societies. However, nothing is impossible according to Birch's 'truth contingency theory'. Indeed, Gaza has challenged all these truth ideologies, to be replaced by new truths that have been confirmed indelibly by the TV and Web pictures watched and viewed by everybody, everywhere the world over.

The fact of the matter is that, after Gaza, the so-called unchallenged truth ideologies have been anti-truths fabricated a long time ago by Zionist and pro-Israel institutions and lobbies. In other words, these discoveries of the new truths about Israel are in fact no more than a new exploration of the original truths and a throw-back to the brass tacks about them, that the West have been 'colonised' and beaten to deception by them for a long time.

Chief among the serious ideologies about Israel that have been challenged here are (i) the borrowing of the Israelis from the Nazi playbook, and (ii) the description of Gaza as 'a large Israeli concentration camp'. Both stand in sharp contrast to the Israeli/Zionist anti-Nazi ideology which was exploited by Israel to blackmail the International Community, especially the West. The same Nazi practices and genocides have been committed by the pretentiously anti-Nazi Israelis. Henceforth, the Israelis have now changed into the New Nazi, practising Nazi atrocities on the Palestinians in Gaza in the same way the Nazis allegedly did with the Jews.

This is a reconstruction of a fake, long lasting, stereotyped and naturalised pro-Israel's ideology into a truthful newly emerging and sharply contrastive anti-Israel ideology. The contingencies upon which this ideological shift was based were the Israeli savageries and massacres in Gaza. Truth contingencies are, thus, unstable, but are liable to change when the need arises with new situations and positions.

This article is a good example of how words may be quite telling about the speaker's ideology, especially in political rhetoric. The fact of the matter is that, whether we like it or not, we are beset and besieged by the language of politics. We meet it everyday and everywhere in different forms and sources - in the mass media, in the very chat we have with many others, in work, academic, public and family circles, even in commodity prices. Among the local equivalents we have for politics are "negotiating, budgeting, reporting, referring, taking measures, arbitrating, debating, legislating, passing laws, etc." Politics surrounds us to become an integral part of life.

This text is a reflection and application of Birch's 'contingent theory of communication' which is a theory of ideology. We make sense of the world by classifying it discursively, a view which replaces the assumption that the world has a 'natural' order and structure. Our concerns spring from a desire to right some wrongs; to bring justice to bear in unjust situations, and question the ways in which strategies of a certain conceptualised ideology persist in societies. Indeed, the politics of everyday life is never the same. Truth is always contingent upon who has the most control of these and other strategies. The translation of this part of the article into Arabic suggested below has taken all these cognitive stylistic considerations of contingency into account: 


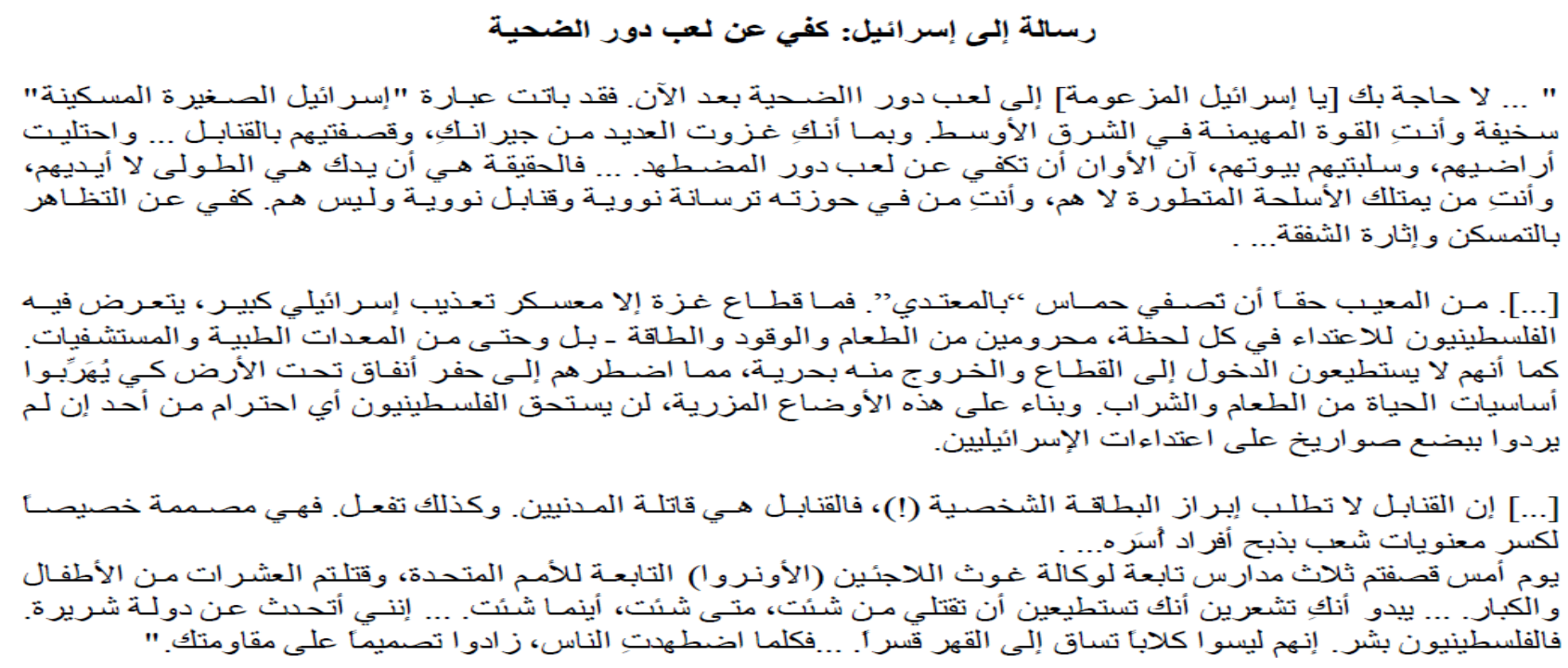

Obviously, the text challenges the naturalness and long-established American and Western pro-Israeli fabricated truth which represents Israel as a poor and oppressed state. However, the atrocities and massacres committed by Israel in Gaza over three weeks (in December 2008 and January 2009) have scandalized that misleading truth. Thus, Slater, the American journalist, has challenged the naturalness of such long-lasting, anti-truth Western ideologies through the following words and expressions juxtaposed with the dogmatized ones (the full text of the original (which can be seen online) is taken into account in the following analysis):

Dogmatized, anti-truth ideologies

-Israel plays the Victim Role

ك كني عن لعب دور الضحية

-Long persecuted Jews

دولة يهودية معتدية من باب تغيير شكل

-Israel acts like a victim

بنبغي على إسر ائيل آلا تلعب دور

-Poor little Israel الضحية بعد الآن النيل

تبدو هذه العبارة سخيفة لأن إسرائيل

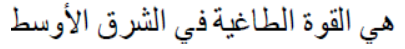

-Israel is threatened by Arabs إسر ائيل غزتهم واحتلت أر اضيهم

-Israel acts the oppressed وسلبتهح بيوتهم غزتهم كطر ف مضطعد الأوان أن تكفي عن التصرف

-The Arabs have the upper hand لالاسر ائيل اليد الطو لـ وليس لهر

-Arabs have sophisticated arms تمنلك إسر ائيل - وليسو ا هم أسلحة متطورة

-Both sides have no nuclear weapons

أبرا أئيل و حدها تملك أسلحة نووية،

-Israel pretends to be pathetic

ـ يجب آن تكف إنر ائيل عن التمسكن

-Americans don't talk about

Israel (being a terrorist, evil empire)

يجب آن يتحثث الأمريكيون عن إسر ائيل

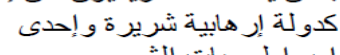

-Israel's calling Hamas

Aggressor is dignified وصف إسر ائيل لحماس بالمعندي

$$
\text { أمر معيب }
$$

-Hamas is the aggressor $\rightarrow \quad$ Truthful ideologies

$\rightarrow \quad$ Stop playing the Victim Role

$$
\text { تلعب إسر ائيل دور الضحية }
$$

$\rightarrow$ A Jewish State is an aggressor for a change

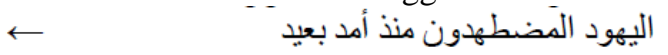

$\rightarrow \quad$ Israel should not act like a victim any more.

$$
\text { تتصرف إسر ائيل وكأنها ضحية }
$$

$\rightarrow$ This phrase sounds silly for she is the dominant power in the Middle East إسر ائيل الصغيرة المسكينة

$\rightarrow \quad$ Israel invaded them and occupied their land and taken their homes

$$
\leftarrow \text { إسر ائيل مهددة من العرب }
$$

$\rightarrow \quad$ It's time to stop acting oppressed

تتصرف إسر ائيل كطرف مضطهد

$\rightarrow \quad$ Israel has the upper hand and they don't.

$$
\text { للعرب اليد الطولى }
$$

$\rightarrow \quad$ Israel has sophisticated arms and they don't.

بمنألك العرب أسلحة منطورة

$\rightarrow \quad$ Israel only has nuclear weapons weapons and Arabs don't. كلا الطرفين لا يملك أسلحة نووية

$\rightarrow \quad$ Israel should stop being pathetic. إسر ائيل تتمسكن

$\rightarrow \quad$ Americans should talk about Israel as a terrorist, rogue state and evil empire. لا يتحدث الأمريكيون عن إسر ائيل

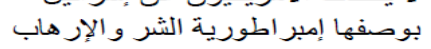

$\rightarrow \quad$ Israel's calling Hamas aggressor is undignified

وصف إسر ائيل لحماس بالمعتدي أمر غير معيب

$\rightarrow \quad$ Israel is the aggressor. 


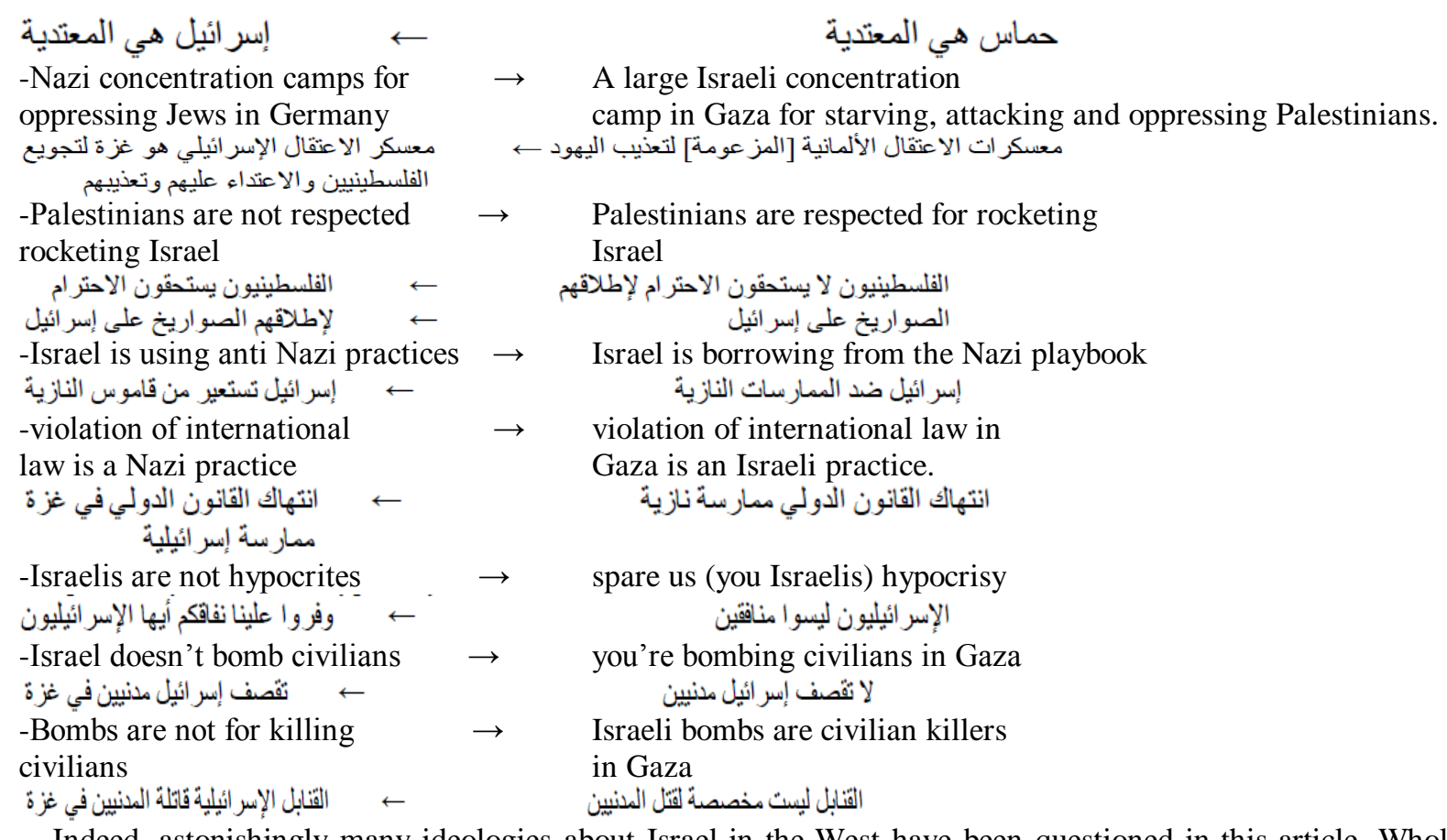

Indeed, astonishingly many ideologies about Israel in the West have been questioned in this article. Whole sociopolitical, socio-cultural, pro-Israel and anti-Arab conceptions have been challenged and have, therefore, to be changed. The old truth ideologies have, after the Gaza massacres, proved to have been anti-truths. In other words, these facts of the new truths about Israel are new explorations of the original facts that the West has been misled by for so long. Thus, a number of ideologies about the Israelis and the Palestinians have been challenged here. All truth contingencies upon which these ideological shifts were based were the Israeli savageries in Gaza in 2009.

All these are good reasons for the translator to focus exceptionally on the construction of these weighty implications of the stylistic choices of the original into the target text, as suggested in the above translation. Some ideological terms and expressions have been added on pro-Arab individual and national attitude and culture. The qualifying adjective 'المزعومة' (alleged) is added after 'Israel' and 'State of Israel' between two brace brackets as an indication of the rejection of the overwhelming majority of the target readership to recognise it.

Both terms, دول محور الثر / إمبراطوريات الثر ('rogue States'/“evil Empires') are translated in accordance with the currently and recently recognised translations, which are coined by the American political idiom to describe antiAmerican and anti-Israel States. On the other hand, تغيير شكل (for a change) is informal in use and is preferred to the formal phrase من أجل التغيير / من باب التغيير for it is more sarcastic and pejorative than the latter.

\section{Sociocultural CONTINGENCY}

Here is an example from literary discourse, to discuss from this contingent ideological perspective of social and cultural background:

“[...] The pub was full of truckies and construction workers, drinking beer and eating pasties.

$[\ldots]$

The baker dug me in the ribs. 'I come from Salamanca,' he screeched. 'Is like a bullfight, no?'

Someone else shouted, 'The Boongs are fighting,' although they weren't fighting - yet. But the drinkers, jeering and cheering, began shifting down the bar to get a look.

$[\ldots]$

'Ole'! shouted the Spanish baker, his face contorted into grimace. 'Ole'! Ole'!'

(Chatwin, The Songlines. 1987. See Birch, 1995 for the whole text)

To many, this text is of little value and perhaps not worthy of reading, or commenting on. This is not surprising in terms of its lexical meaning (or subject matter), for there is nothing interesting about the theme, characters or events. However, a cognitive reading of style that is culturally and ideologically based can make something of this text. According to this reading, we read texts with our diverse background knowledge and mentality, and not with the writer's background knowledge. Thus, we, the readers, make meanings. They are not ready-made by writers. Writers construct them in terms of their own cognitive backgrounds, but readers reconstruct them in their own terms of constantly changing cognitive knowledge. Additionally, meanings are not stative, waiting there for us to construct them in the same way, and with the same contingencies that have already been framed by our social, cultural, ideological and/or political communities and institutions. We use them at will as indisputable, consensual sources of interpretations, against which we draw value judgments that no one can deny or defy. 
The text's setting is Australia. As everybody knows, Australia is a multi-cultural country in which communities of different cultures have to live together, despite their differences. They have demonstrated a great deal of understanding each others' cultural differences, yet the feeling of belonging to one's original culture and the non-belonging to others' cultures has its roots in this text. Birch isolates what he calls 'character classifications':

"Truckies, construction workers, the Outback male tourists, Land Rights lawyers, the blacks darling, a stingy little man, Park Warden, Yer dirty Gin, missus, a Spaniard, the town baker, two Aboriginals, Aboriginal, the other, a scrawny boy, the man, the boy, the baker, someone else, the Boongs, the drinkers, the Aboriginal man, the truckie, the older man, the man, the Spanish baker, the bouncer, the two Aboriginals, the Spaniard, best friends. "

This positioning of the character classification here may suggest an uncomfortable stereotyping of Aborigines, women, workers, Spaniards, white tourists and travel writers / narrators. There is a major divide between regular occupants of the pub, and the passers-by, more distanced and more sophisticated tourist, the white Australians in the pub and the Aborigines; between the white people of the town and the blacks who claim back their land; and between the 'uncivilised' value systems of the Outback pub culture of Australia and the 'civilised' value systems of elsewhere.

These are among the important issues to be considered in this passage. They are ideology-oriented. More issues are suggested by questions also posed by Birch (ibid.) at reading this text:

-Whose culture are we reading/writing here?

-What values do we privilege?

-Are these values contingent upon racism, intolerance, bigotry, justice, injustice, multi-cultural embrace, or ethnocentric narrow-mindedness and inexperience?

-Finally, I may ask, aren't such questions a matter of an individual reader's ideology?

In reply to the final question, yes, all these questions are questions of 'ideology of reading'. The reader applies his/her own ideology (religious, social, political and cultural) he/she personally and individually entertains. Birch poses good questions including the first two about whose culture and whose values we, the readers, apply when we read such a text.

Thus, at reading this passage here, we are more likely to read it, bringing our own background mentalities, cultures, values and ideologies. What we have here can be described as 'Pub Culture'. This culture is a Western culture that all characters involved in the text, as well as Birch, take it for granted to be a matter of course in their ideology. That is why Birch did not include 'pub, drinking beer, buttocks, and I took my drink' in his list of ideological words and expressions. However, and in response to Birch's questions about whose culture and whose values we reconstruct, 'pub culture' is not a part of many nations' cultures, including Muslim nations. Even the words 'pub', 'beer' and 'take a drink' are not normal in Islamic culture, for they are prohibited in Islam.

Further, taboo words are quite sensitive to Islamic as well as some eastern cultures, which is why I have left a few lines out of the passage above. These words may discourage Muslim and many eastern readers from reading the text in the first place. This stresses religious culture as one of the major contingencies upon which ideology is based, for some cultures at least. This contingent component of ideology seems to have been marginalized by many stylisticians including Birch (ibid.). This contingency component can be sometimes decisive for religion-committed readers' ideologies. Indeed, cognitive-ideological stylistics may be interesting and useful for its realistic, truthful and everrenewed truths, bases and principles.

The text is obviously literary, including a number of cultural dialect words and expressions. The characters are noneducated and use their own dialects. The style is, therefore, rather colloquial. When translating the passage, it might be a good idea to translate dialect words into Arabic equivalents to reflect the colloquial tone of the original, as suggested by the following version:

(1)

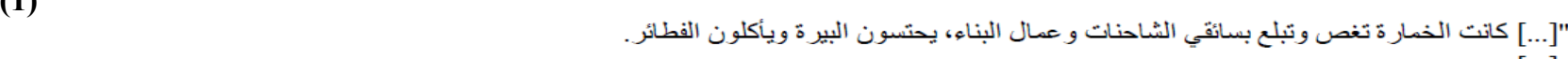

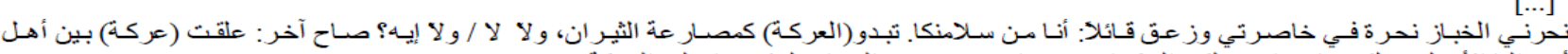

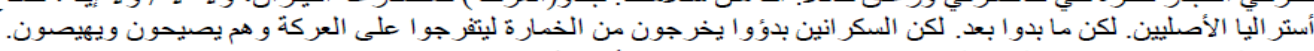

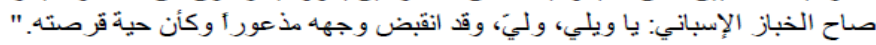

Some of these words and expressions are local dialects. For example, خمارة (instead of the more formal, خانة) (pub) (a widely known Arabic dialect); تغص وتبلع (full of L crammed with) (Syrian); نحرنتي...نحرة ('dug me in the ribs’) (Syrian);

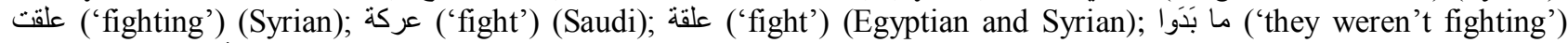

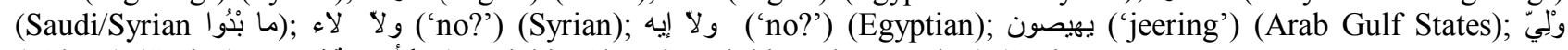
('Ole'!') (Syrian); وكأن حية قرصنه ('panicking'/‘as though bitten by a snake') (Syrian).

Other expressions are used in both formal and dialect Arabic (e.g. خمارك ('bar'); باويلي (Ole !').

This version of translation has preserved the dialectal tone of style of the source text. Therefore, it seems to have achieved the maximum degree of transforming meaning and effect of the style of the original. This is partly true, but not to one's satisfaction. First, the Arabic language is a conservative language that, despite many anti-standardisations and pro-dialectalizations of written Arabic, the Arabic dialect is still alien to writing in general, and literary texts in 
particular. One or two exceptions of dialectal use might be allowed for emphatic, humorous, ironical or other peculiar stylistic reasons. As a result, the frequent use of Arabic dialect words and expressions in a translated text would cause negative reactions against it and its translator from the target readers, who take it as a sign of disrespect for the Language of the Holy Koran.

More importantly, dialect words jeopardise changing the style of a serious text into a less serious, or even sarcastic, style, in which case the whole translation might collapse. Above all, which dialect of the Arab country is the translator going to use, bearing in mind that he/she translates to an Arab readership? The best way to achieve a sort of unanimity of Arab readership is to give up dialects in favour of formal Arabic, whether Classical or, more agreeably, Modern Standard Arabic (MSA), a variety of which is perfectly formal and more simplified and which uses modern words and expressions. Dialect is still strongly confined to spoken discourse in Arabic.

On the other hand, cultural connotations and implications are ignored in this translation. Many cultural hints have been left covert where they should be constructed and made overt to target readers to enable them to get into the world of the style of the source text. The next version of translation of the same text suggests some kind of solution to the two major problems of dialectal and cultural deficiencies of translation (1).

(2)

$$
\begin{aligned}
& \text { "[...] كانت الحانة تغص بسائقي الشاحنات و عمال البناء، يحتسون البيرة ويأكلون الفطائر. }
\end{aligned}
$$

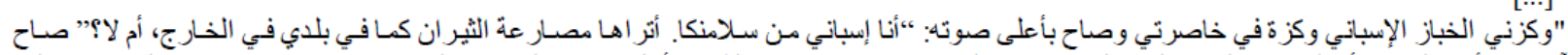

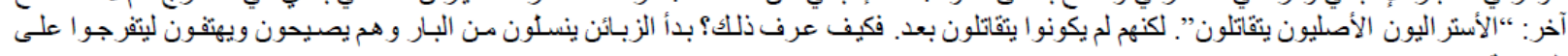

$$
\begin{aligned}
& \text { المعركة. } \\
& \text { صاح الخباز الإسباني: "يا للهول!"، وقد انقبضت قسمات وجهه وارتعدت فر ائصده من شدة الذعر و الثقزز." }
\end{aligned}
$$

In this translation, dialect words and expressions are disposed of for good reasons. Literary language is expected to be formal only, Classical and MSA. More so, Classical Arabic is more frequently used in literary texts, traditional and modern, than MSA. Unlike Modern English views, which refuse the division between literary and non-literary language (e.g. Fowler, 1981/1985; Carter and Nash, 1990; Boase-Beier, 2006 and all contemporary stylisticians), this polarization sustains in Arabic. Arabic Literary language, especially poetry, is viewed as a special language, not inherently (which comes to terms with current English views), but in terms of language patterning and prosodic features in particular. Therefore, dialect is not expected by Arab readers to be used in literary translation for the reasons just pointed out. The dialect words of (1) above are replaced by formal ones, which makes the translation formal and normal, thus conforming to the stylistic traditions and requirements of translating literature into Arabic. A careful juxtaposition of (1) and (2) above may illustrate dialect differences easily.

That said, the process has not been a mere replacement of a colloquial word or expression with another equivalent formal one. Other factors are involved. For example, وكزني ... وكزة' is a classical collocation that is different from the informal 'نحرني ... 'نحرة' both in sense and effect. More importantly, the latter is rather painful and connotes dissatisfaction, whereas the former is not painful and connotes humor and attracts somebody else's attention to something. In a similar way, the second 'خمارة' (bar) is substituted for 'بار' not so much for dialectal as for cultural reasons, to avoid using it for its unfavourable sense for the majority of target readers. Thus, by using the transferred term, بار, the cultural factor has been realised, and at the same time it is referred back to its foreign, non-Arab source. However, this does not apply to كاونتر (counter) which is a dialect transferred word. Therefore, it has been replaced by the formal word منصة.

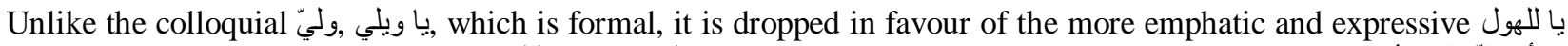

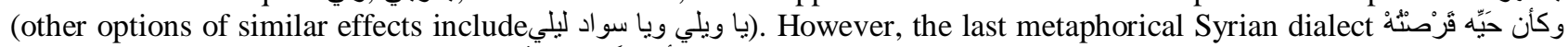

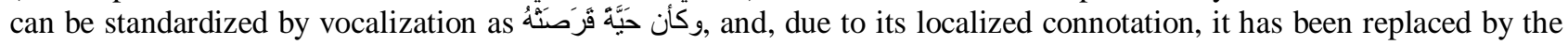
similarly effective formal, well-known expression ارتعدت فر ائصدان

On the other hand, some words and expressions have been modified, qualified, extended, over-emphasised, dropped or replaced for stylistic and cultural reasons. For example, الإسباني (Spanish) is added to pre-modify 'baker' to pinpoint his cultural belonging; the same applies to إسباني to introduce the same character from Salamanca, as many target readers do not know the whereabouts of this city. On the other hand, stating the nationality and cultural origins of characters plays a pivotal role in our understanding and interpretation of the source text's stylistic choices, which would be constructed by the translator in the target language. Also, the 'Boongs' is translated into الأستر اليون الأصليون, 'Aboriginal man' into سائق الثناحنة الأستر الي الأصنر الي الأصلي and 'truckie' into emphasise the strong cultural and racial ties between them, which illustrates much about the implications of people's action and reaction to the fight. Hence the addition of the phrase من بني جنسا (compatriot) with the aims of underpinning the character's strong links with the Aboriginal man.

In addition, other expressions are understood from the source text by implication, and have accordingly been

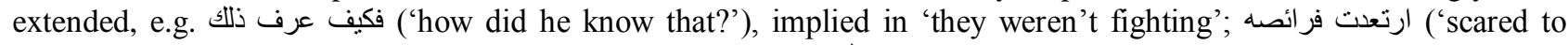
death'/'scared out of his wits'), implicated by 'in grimace'; في بلدي ('in my country'), connoted by 'bullfight'. Other terms have been preferred for their greater effect and emphasis, for example ينسلون ('shift away') and دس ('shoved it').

All the above are examples of conceptualisation of stylistic choices in their original context. Extensions like these are extensions of the characters'/speakers' ideas triggered by certain stylistic choices which are made in their cultural, 
mental and ideological backgrounds. Many of the extended terms and expressions (such as 'my compatriot' and 'in my country') are ideology-laden, expressing a political or racial attitude on the part of the characters involved. 'Truckie' is a dialect word that has been ideologized through its dialectal use and, in the translation, through stating the truckdriver's nationality and culture which is behind his mentality (of aggressiveness and trouble-making) and attitude (of supporting and encouraging his compatriot).

For all these reasons taken together, the second version of translation, which is constructed on cognitive stylistic bases, might have dug in deep for the actual meanings and effects of the source text.

Perhaps the very latest on contingency theory is what may be described as 'revolutionary contingency'.

\section{REVOLUTiOnARY CONTINGENCY}

The surprising thing is that many of the older, original terms have lately made a strong come back to the media, especially 'revolutionists', resistance, Zionism, Zionists, Zionist Entity and long live (cf. the Tunisian, Egyptian, Libyan, Yemeni, Syrian, etc. revolution in 2011 (الثورة التونسية / المصرية / الليبية / اليمنية / السورية، إلخ. (في عام (النقاية)); 'Long live Egypt' (تحيا مصر / عاثت مصر); Palestinian Resistance (المقاومة الفلسطينية / اللبنانية)); etc.

The latest Arab revolutions in 2011, especially the Tunisian and Egyptian revolutions -which were more peaceful than others revolutions - have changed several long-established ideas, ideologies, socio-cultural concepts and traditions, especially the political ones. For convenience of argument, focus will be on the more significant of the latter two revolutions and perhaps, specifically the most significant of all Arab revolutions in modern Arab history, the Egyptian revolution. Let us start with the established ideologies and cultural concepts of political nature which had been prevalent covertly and overtly among people:

(a) Demonstrating against the regime is banned.

(التظاهر ضد النظام مهنوع (b)

(b) The National security police and intelligence are intimidating. (إن شرطة أمن الدولة، و المخابر ات (أو الثرطة السرية) أجهزة مرعبة

(c)Dictatorial rule is unquestionable. (الحكم الدكتاتوري غير قابل للنقاش)

(d) Never say 'No' to the police. (لا تقل 'لا، للشرطة أبداً)

(e) Anti-governmental slogans are categorically banned.

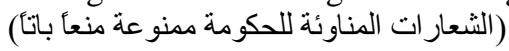

(f) The breach of curfew is impossible to anticipate. (إن خرق قانون منع التجول غير متوقع على الإطلاق)

(g) Pharaoh culture is an unquestionable symbol of national pride, civilization and long-lasting Egyptian tradition. (إن الثقافة الفرعونية رمز وطني وحضاري ونر اث مصري عريق غير قابل للنقاش)

(h) The President never makes mistakes. (الرئيس لا يخطئ أبداً / الرئيس معصوم من الخطأ)

(i) Islamic religiousness is a glaring sign of fundamentalism and terrorism. (التدين الإسلامي إثشارة فاقعة للأصولية و الإرهاب)

(j) The Holy Koran and the Cross can never coexist in peace in Egypt. (القرآن الكريم والصليب لا يتعايثان أبداً في مصر )

(k) Establishing strong ties and normalization of relations with Israel is plausible. (إقامة أو اصر قوية وتطبيع العلاقات مع الإسر ائيليين أمر مقبول)

(1) The martial law is in effect indefinitely. (قانون الطوارئ ساري المفعول إلى أجل غير مسمى)

(m) Mixed demonstrations are unimaginable. (المظاهر ات بمشاركة الجنسين أمر غير وارد)

(n) The Egyptian youths are useless and hopeless. (الثباب المصري عديم النفع ولا أمل فيه)

(o) The age of revolutions in a conventional way has become history. (لقد ولى زمان الثورات القليدية)

(p) The age of old-fashioned national, enthusiastic and inspiring songs has gone. (لقد ولى زمان الأغاني الوطنية الحماسية القيمة)

(q) The million-demonstrations are unimaginable. (المظاهر ات المليونية غير واردة)

(r) People are submissive, afraid, cowardly, so they will never revolt against the regime. (الناس أذلة، وخائفون، وجبناء، لذا لن يثوروا على النظام أبدآ)

(s) The Country's army is a pro-regime's army. (جيش البلاد هو جيش النظام)

(t) The people run away from the police. (يهرب الناس أمام الثرطة) 
(u) People only listen to the President, but they are not listened to.

(الناس بستمعون للنظام فقط، لكنه لا يستمع إليهم أبدأ)

(v) Pro-regime camel thugs, ruffians, gangsters, muggers and boot boys are history.

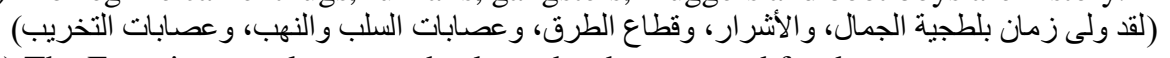

(w) The Egyptian people are too backward to be prepared for democracy.

(الثعب المصري متخلف و غير جاهز للايمقر اطية)

(x) The Egyptian people cannot demonstrate peacefully in a civilized way. (الشعب المصري غير قادر على التظاهر سلمياً بطريقة حضارية)

(y) The Egyptian people - if and when - may demonstrate only violently. (يتظاهر الثعب المصري - هذا إذا نظاهر - بعنف فقط)

(z) Nobody in Egypt or in the whole world expects the Egyptian youths to revolt in millions against their regime. (لا يتوقع أحد في مصر أو في العالم أجمع أن يثور الثباب المصريون بالملايين ضد نظامهم)

(aa) No freedom of expression is foreseen in the near future in Egypt. (لا يُتوقع حرية تعبير في المسنقبل القريب في مصر )

(bb) The Arab peoples, including the Egyptians are viewed by their dictatorial regimes as lethargic, obsequious, timid, meek, spiritless, slavish and driven like lambs to the slaughter.

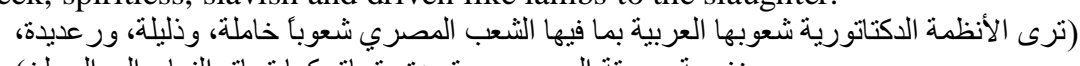

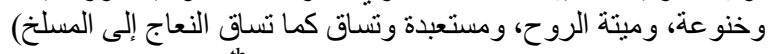

Yet, after the $25^{\text {th }}$ of January Egyptian Youth Revolution at at-Tahrir Square and elsewhere in Alexandria, Mansurah, Suez and several other Egyptian main cities, all these allegedly age-old traditions and ideologies have changed drastically as follows (this list should be considered in contrastive juxtaposition with the first one above):

(a) Demonstrating against the regime is allowed, whether it likes it or not. (النظاهر ضد النظام مسموح به شاء أم أبى) (bolinte)

(b) The National security police and intelligence are not intimidating. (شرطة أمن الدولة، والمخابر ات و الثرطة السرية أجهزة غير مر عبة)

(c) Dictatorial rule is questionable. (الحكم الدكتاتوري قابل للنقاش) (dou (ان)

(d) You can say 'No' to the police. (تستطيع أن تقول 'لا' للشرطة)

(e) Anti-president and anti-government traditional slogans are common (الثعار ات المناؤئة للحكومة شائعة) (e.g. 'The People wants to oust the regime!'; 'The People wants to oust the government!'; 'Get out / leave the Country, President!') (e.g.

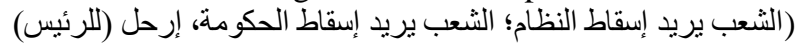

(f) Breach of curfew is possible to anticipate. (خرق قانون منع التجول منوقع)

(g) The Pharaoh culture is a symbol of dictatorship and oppression, as in Islamic culture. (الثقافة الفرعونية رمز للاكتاتورية والقهر، كما هي حالها في الثقافة الإسلامية)

(h) The President may make fatal mistakes. (قد يرنكب الرئيس أخطاء قاتلة / الرئيس غيرمعصوم)

(i) Islamic religiousness is normal and has no relation to terrorism. (التدين الإسلامي أمر عادي ولا يمت بصلة للإز هاب)

(j) The Holy Koran and the Cross can coexist in peace in Egypt (as it has been confirmed at At-Tahrir Square of Cairo when Al-Azhar Muslim scholar and a priest raised the Holy Koran and the Cross up hand in hand before the whole world in February, 2011).

$$
\begin{aligned}
& \text { (يمكن للقر آن الكريم و الصليب أن يتعايشا بسلام في مصر ) (كما تأكد في ميدان التحرير في القاهرة عندما قام التحام }
\end{aligned}
$$

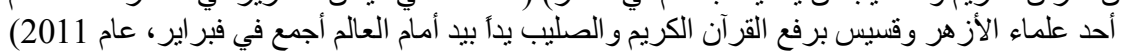

(k) Establishing strong ties and normalization of relations with the so-called Israel is deplorable. (إقامة أواصر قوية وتطبيع العلاقات مع ما يسمى بإسر ائيل أمر مستنكر )

(1) The martial law should be lifted very soon indefinitely. (ينبغي رفع قانون الطوارئ على الفور إلى أجل غير مسمى)

(m) Mixed demonstrations are normal. (المظاهر ات بمشاركة الجنسين أمر طبيعي)

(n) The Egyptian youths are quite useful and have high hopes. (الثباب المصري عظيم النفع وذو آمال عريضنة)

(o) The age of conventional revolutions has never gone, but changed style. (ما ولى زمان الثور ات التقليدية أبدأ ولكن تغير الأسلوب)

(p) The age of classic national, enthusiastic and inspiring songs has come back. (لقد عاد زمان الأغاني الوطنية الحماسية القديمة)

(q) The million-demonstrations are quite imaginable. (المظاهر ات المليونية ممكنة جداً)

(r) People are brave, fearless, resolute, audacious and able to revolt against the regime. 


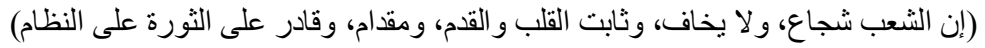

(s) The Country's army is the people's army.

(جيش البلاد هو جيش الثعب) (ج)

(t) The police run away from the people.

(تهرب الثرطة أمام الناس)

(u) The President listens to the people.

(الرئيس يستمع للثعب/ لمطالب الثعب)

(v) Pro-regime camel thugs, ruffians, gangsters, muggers and boot boys have been brought back in the third millennium by the deposed Egyptian regime.

$$
\begin{aligned}
& \text { ( عاد زمان بلطجية الجمال، وشذاذ الآفاق، وقطاع الطرق، و عصابات السلب و النهب، و عصابات }
\end{aligned}
$$

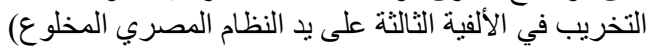

(w) The Egyptian people are too civilized and ever prepared for democracy.

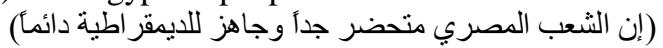

(x) The Egyptian people have set an example for the whole world in how to demonstrate peacefully in a civilized way and change oppressive regimes.

$$
\text { (لقد ضرب الثعب المصري مثلا يحتذى للعالم بأسره في كيفية النظاهر سلميأ بطريقة حضارية }
$$

وتغيير الأنظمة القمعية)

(y) The Egyptian people never demonstrate violently.

(لا يتظاهر الثعب المصري بعنف إطلاقً)

(z) Nobody in Egypt or in the whole world expected the Egyptian youths to revolt in millions against their regime, but they disappointed everybody and did it).

$$
\begin{aligned}
& \text { (لم يتوقع أحد في مصر أو في العالم أجمع أن يثور الثباب المصريون بالملايين ضد نظامهم، لكنهم } \\
& \text { خيبو آمال الجميع وفعلوها) }
\end{aligned}
$$

(aa) Freedom of expression is a reality now in Egypt.

(إن حرية التعبير حقيقة واقعة الآن في مصر )

(bb) The Arab peoples, including the Egyptians are spirited, alive, energetic, inspired, steadfast, revolting, ardent, active and never driven to slaughters like lambs anymore.

$$
\begin{aligned}
& \text { (إن الثعوب العربية بما فيها الثعب المصرب شعوب حية، ونابضة بالحيوية، وطموحة، وقوية الثكيمة، }
\end{aligned}
$$

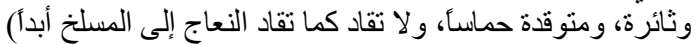

In the light of these changes of dogmatized political ideologies, mentalities, cultures and long established, but fake traditions, the language of politics and its implications are expected to change tremendously. Consequently, the emergence of these new meanings would change a great deal of the people's perception of life as a whole. Therefore, these changes are approached and translated in terms of a cognitive perspective of contingency, mobility, freshness and renewal of political, social and cultural ideologies, attitudes and concepts.

\section{CONCLUSIONS}

We may conclude from this investigation of the repercussions of the contingency theory of change on the translation theory and practice that the latter has to match the former and respond positively to it. That is, the translator has to bear in mind the temporality of political, cultural and social ideologies, attitudes and traditions which are susceptible to change. This change should be reflected and matched in translation through a cognitive approach that can be flexible enough to accommodate it any time, anywhere. This leads in effect to suggest a parallel contingent theory of translation that is flexible enough to adapt to any unforeseen changes in traditional implications and ideologies.

The translation procedures that are recommended to be employed are mainly cognitive, allowing for more freedom and courage on the translator's part to add, change, modify, delete, illustrate and create new terms and concepts. He/she can use at liberty any of the following procedures as applicable: paraphrase; overtranslation (or specification); undertranslation (generalization); expansion; deduction; neologism; euphemization; addition; deletion; classifiers; translation couplet; translation triplet; calques (or foreignization); naturalization; transference (or transliteration); proximity; culturalization; and deculturalization / neutralization (or the use of universals / internationalisms). (For illustrations and procedures, see Newmark, 1988, Ghazala, 2008, 2011 and 2012 (forthcoming); Baker, 1998; Robinson, 1997/2007; Bell, 1991; Alvarez, 1996; Venuti, 1996 and 2004 and several others) ).Obviously, translation theory is expected to be compatible with any emerging theory that concerns meaning and any new changes, means, procedures and theories that may affect our perception of it. A case in point nowadays is the contingency theory of perception of ideologies and attitudes of different kinds and how it reflects upon cognitive translation theory. Indeed, many things are prone to change and translation theory and practice is no exception.

\section{REFERENCES}

[1] Alvarez, R. \& M. Vidal M.(ed.)(1996). Translation, Power, Subversion. Clevedon, Philadelphia, Adelaide: Multilingual Matters Ltd.

[2] Baker, M. (ed.) (1998). Routledge Encyclopaedia of Translation Studies. London and New York: Routledge.

[3] Bell, R. (1991). Translation and Translating. London and New York: Longman. 
[4] Birch, D. (1995). Strategy and contingency. In P. Verdonk \& J. Weber (eds.) (1995). Twentieth-Century Fiction: From Text to Context. London and New York: Routledge, 220-34.

[5] Birch, D. (1989). Language, Literature and Literary Practice, London: London and New York: Routledge.

[6] Boase-Beier, J. (2006). Stylistic Approaches to Translation. Manchester, UK \& Kinderhook, USA: St. Jerome Publishing.

[7] Carter, A. and Nash, W. (1990). Seeing Through Language: A Guide to Styles of English Writing, Basil Blackwell.

[8] Fowler, R. (1981/1985) Literature as Social Discourse: The Practice of Linguistic Criticism. London: Batsford.

[9] Gavins, J. (2000). Absurd tricks with bicycle frames in the text world of The Third Policeman. Nottingham Linguistic Circular $15,17-33$.

[10] Gavins, J. (2005). Text world theory in literary practice. In B. Petterson, M. Polvinen, \& H. Veivo (eds.), Cognition and Literary Interpretation in Practice. Helsinki: University of Helsinki Press. 89-104.

[11] Gavins, J. (2007). Text World Theory: An Introduction, Edinburgh: Edinburgh University Press.

[12] Gavins, J. \& G. Steen (2003). Cognitive Poetics in Practice, London \& New York: Routledge.

[13] Ghazala, H. (2011). Cognitive Stylistics and the Translator. London: Sayyab Books.

[14] Ghazala, H. (2012). Translating the Media and Political Idiom: A Textbook for University Students. Jeddah, Saudi Arabia: Konooz Al-Marifa.

[15] Gutt, E. (2000). Translation and Relevance ( $3^{\text {rd }}$ edn.). Manchester: St. Jerome.

[16] Gutt, E. (2005). On the significance of the cognitive core of translation. The Translator 11.1, 25-49.

[17] Jeffries, L. (2010). Stylistics. Cambridge: Cambridge University Press.

[18] Robinson, D. (1997/2007). Becoming a Translator. London and New York: Routledge.

[19] Simpson, P.(2004). Stylistics: A Resource Book for Students. London \& New York: Routledge. Slater, P. A Message to Israel. http://www.huffingtonpst.com (accessed 1/7/2009).

[20] Stockwell, P. (2002a). Cognitive Poetics: An Introduction. London \& New York: Routledge.

[21] Stockwell, P. (2002b). Miltonic Texture and the feeling of Reading. In E. Semino, \& J. Culpeper. (eds.), Cognitive Stylistics: Language and Cognition in Text Analysis. Amsterdam \& Philadelphia: Benjamins, 73-94.

[22] Venuti, L. (1992). Rethinking Translation. London and New York: Routledge.

[23] Venuti, L. (1995). The Translator's Invisibility: A History of Translation. London and New York: Routledge.

[24] Venuti, L. (1996). Translation, heterogeneity, linguistics. TTR, 9, 1, 91-113.

[25] Venuti, L. (1998). The Scandals of Translation, London and New York: Routledge.

[26] Venuti, L. (ed.) (2000/2004). The Translation Studies Reader. London and New York: Routledge.

[27] Verdonk, P. (1999). The liberation of the icon: A brief survey from classical rhetoric to cognitive stylistics. Journal of Literary Studies 15.3/4, 291-304.

[28] Verdonk, P. (2002). Stylistics. Oxford: Oxford University Press.

[29] Verdonk, P. \& J. J. Weber (eds.) (1995). Twentieth-Century Fiction: From Text to Context. London and New York: Routledge.

[30] Weber, J.J. (1992). Critical Analysis of Fiction: Essays in Discourse Stylistics. Amsterdam: Rodopi.

[31] Weber, J.J. (1996). The Stylistics Reader. London: Arnold.

[32] Weber, J.J. (2005). From "Bad" to "Worse": Pragmatic scales and (de)construction of cultural models. Language and Literature 14.1, 45-63.

Hasan Said Ghazala is a Professor of Stylistics and Translation at the Department of English, Umm Al-Qura University, Makkah Al-Mukarramah, Saudi Arabia. He holds an MA in Translation \& Linguistics (Bath University, UK, 1983), and a Ph.D. in Stylistics (Nottingham University, UK, 1987). he taught translation, style and stylistics in several Arab Universities (Aleppo, Oran, Tripoli, and Umm Al-Qura and still). He has contributed to, and is a member of a number of international conferences and symposia on translation and stylistics. He supevised and examined many MA and Ph.D. Theses on translation in particular. He has published many research papers (37 so far) on translation and stylistics in several international refereed journals and periodicals most of them are collected in his book, Essays in Translation and Stylistics). Also he has published several books (as yet 16) on translation and stylistics, including: Translation as Problems and Solutions: A Textbook for Uinverstiy Students and Trainee Translators (2008); AlJame' Fi t-Tarjama (Trans. of Newmark's A Textbook of Translation (1988), 2006); Varieties of English Simplified: A Textbook for Advanced Uinverstiy Students, (1994); a Dictionary of Stylistics and Rhetoric, (English-Arabic-English), (1996); Stylistics, Interpretation and Teaching, (in Arabic) (1998); Essays in Translation and Stylistics (2004); Dar El Ilm Dictionary of Collocations (English-Arabic) (1536pp) (2007); Librairie du Liban Dictionary of Collocations (Arabic-English), (around 800pp) (2011); Cognitive Stylistics \& The Translator, Sayyab Publications, (London, UK, 2009); Translating the Media and Political Idiom (2012); and Encyclopedia of Practical Translation (English-Arabic-English (10 Vols.) (forthcoming). 